Supporting Information containing 17 pages, 3 Tables and 8 figures to accompany

manuscript titled

\title{
Is Superoxide Mediated Fe(III) Reduction Important in Sunlit Surface Waters?
}

Guowei Xing, Shikha Garg, and T. David Waite*

School of Civil and Environmental Engineering, The University of New South Wales, Sydney, NSW 2052, Australia

Environmental Science \& Technology

*Corresponding author: Phone+61-2-9385 5060; Email d.waite@unsw.edu.au 


\section{S1 Additional experimental details}

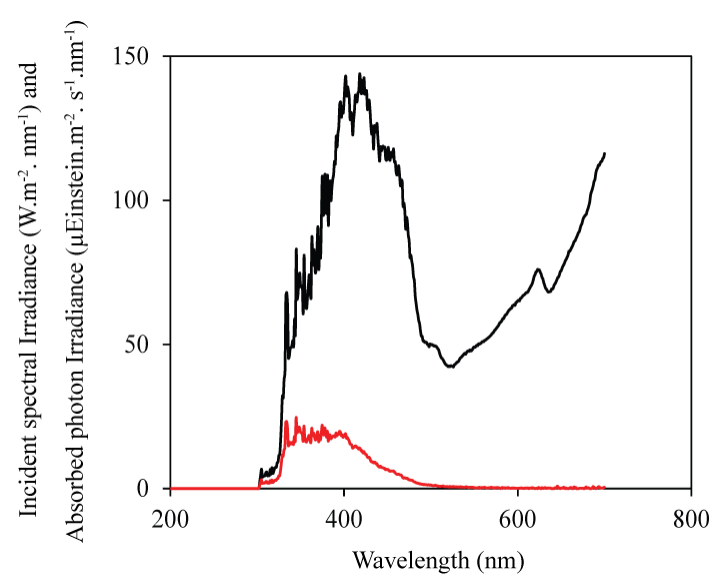

Figure S1: Measured incident spectral irradiance of the Xe lamp and absorbed photon irradiance of $10 \mathrm{mg} . \mathrm{L}^{-1}$ SRFA solution. This data is obtained from an earlier study by Garg and co-workers. ${ }^{1}$

\section{S1.1 Experimental Setup for Fe(III) Reduction Rates}

For measurement of thermal Fe(III) reduction rates in SRFA solution, FZ was mixed with SRFA solution at a final concentration of $1.0 \mathrm{mM} \mathrm{FZ}$. The experiment was initiated by addition of $\mathrm{Fe}(\mathrm{III})$ to $30 \mathrm{~mL} 10.0 \mathrm{mg} . \mathrm{L}^{-1}$ SRFA solution containing $\mathrm{FZ}$ at $\mathrm{pH}$ 8.3. Samples were withdrawn at different times and the concentrations of $\mathrm{Fe}(\mathrm{II}) \mathrm{FZ}_{3}$ formed was measured using Visible spectroscopy. For the Fe(III) reduction experiment in irradiated SRFA solution, the experiment was initiated by addition of $\mathrm{Fe}(\mathrm{III})$ to $3 \mathrm{~mL} 10.0 \mathrm{mg} . \mathrm{L}^{-1} \mathrm{SRFA}$ solution containing 1.0 $\mathrm{mM} \mathrm{FZ}$ and the lamp was turned on immediately ( $10-20 \mathrm{~s}$ delay). Note that in this case $\mathrm{Fe}(\mathrm{III})$ is present as freshly formed $\mathrm{AFO}-\mathrm{L}$ and $\mathrm{Fe}(\mathrm{III}) \mathrm{L}$. The $\mathrm{Fe}(\mathrm{II}) \mathrm{FZ}_{3}$ concentration formed was measured immediately after the lamp was extinguished.

For measurement of thermal and photochemical reduction of preformed bare AFO, AFO suspension was formed by addition of $\mathrm{Fe}(\mathrm{III})$ stock solution to $2.0 \mathrm{mM} \mathrm{NaHCO} 3$ solution containing $10.0 \mathrm{mM} \mathrm{NaCl}$ at $\mathrm{pH} 8.3$ to achieve a final $\mathrm{Fe}(\mathrm{III})$ concentration of 0.5 or $2.0 \mu \mathrm{M}$ while stirring rapidly at $1250 \mathrm{rpm}$ using a $1.5 \mathrm{~cm}$ stirring bar. After $10 \mathrm{~s}$, stirring was stopped 
and the AFO suspensions allowed to age for a certain time prior to measurement of the reduction of these oxides. Mixing is an important factor in controlling the polymerization and aggregation behavior of AFO, hence mixing regimes were closely replicated throughout each experiment. For photochemical reduction of AFO, an appropriate volume of SRFA and FZ stock solution was added to $3 \mathrm{~mL}$ of AFO suspension to achieve a final concentration of 10.0 mg. $\mathrm{L}^{-1}$ and $1.0 \mathrm{mM}$ respectively. Following addition of SRFA and FZ, the AFO suspension was irradiated for $0.5,1,5$ and 10 min and the concentration of $\mathrm{Fe}(\mathrm{II}) \mathrm{FZ}_{3}$ formed was measured immediately after the lamp was extinguished.

For measurement of photochemical reduction of dissolved and colloidal Fe(III), appropriate volumes of $\mathrm{Fe}$ (III) stock were added to the $10.0 \mathrm{mg} . \mathrm{L}^{-1}$ SRFA solution at $\mathrm{pH} 8.3$ in order to achieve final $\mathrm{Fe}(\mathrm{III})$ concentrations of $0,0.1,0.5,1.0$ and $2.0 \mu \mathrm{M}$ after which the solution was left in the dark for 2 hours to reach equilibrium. After 2 hours, a portion of these solutions were filtered using $0.025 \mu \mathrm{m}$ (MCE; $25 \mathrm{~mm}$, Millipore) membranes. As reported earlier, the fraction of Fe present in the $0.025 \mu \mathrm{m}$ filtrate is usually considered to represent dissolved Fe. Thus, to measure the photochemical reduction of dissolved Fe, appropriate volume of FZ stock solution was added to $3 \mathrm{~mL}$ of $0.025 \mu \mathrm{m}$ filtrate to achieve a final concentration of $1.0 \mathrm{mM}$. Following addition of FZ, the $0.025 \mu \mathrm{m}$ filtrate was irradiated for 1,2,5 and $10 \mathrm{~min}$ and the concentration of $\mathrm{Fe}(\mathrm{II}) \mathrm{FZ}_{3}$ formed was measured immediately after the lamp was extinguished. To compare the extent and mechanism of dissolved and colloidal Fe(III), we also measured the photochemical reduction of the unfiltered solution (which constitutes both colloidal and dissolved Fe(III)) using the same procedure as described above. Note there was no change in dissolved organic carbon (DOC) of the solution following filtration suggesting that the SRFA was not removed on filtration.

Note that the presence of $\mathrm{Fe}(\mathrm{II}) \mathrm{FZ}_{3}$ did not affect the light absorption by SRFA since SRFA absorbs in the wavelength range 200-400 $\mathrm{nm}$ while $\mathrm{Fe}(\mathrm{II}) \mathrm{FZ}_{3}$ absorbs near $560 \mathrm{~nm}$. 
Furthermore, as determined in our earlier work, ${ }^{2}$ no impact of $\mathrm{FZ}$ addition was observed on photochemical $\mathrm{H}_{2} \mathrm{O}_{2}$ generation on irradiation of SRFA with this result suggesting that $\mathrm{FZ}$ has no impact on SRFA photochemistry. The maximum absorbance of Fe(III)SRFA is near 400 $\mathrm{nm}$ and hence does not appear to be strongly affected by the presence of $\mathrm{FZ}$ or $\mathrm{Fe}(\mathrm{II}) \mathrm{FZ}{ }_{3}$.

\section{S1.2 Experimental Setup for Superoxide and Hydrogen Peroxide Generation}

For measurement of superoxide $\left(\mathrm{O}_{2}^{\bullet-}\right)$ and hydrogen peroxide $\left(\mathrm{H}_{2} \mathrm{O}_{2}\right)$ concentration generated on irradiation of SRFA, $10.0 \mathrm{mg} . \mathrm{L}^{-1}$ of $\mathrm{pH}$ 8.3 SRFA solution was irradiated for $0.5,1,2,5$ and 10 minutes and the concentration of $\mathrm{O}_{2}^{--}$and $\mathrm{H}_{2} \mathrm{O}_{2}$ was measured immediately after extinguishing the lamp using chemiluminscence method $^{3}$ and fluorescence spectroscopy ${ }^{4}$ respectively as described in detail in the following sections.

\section{S1.3 Fe(II)FZ 3 Measurement}

Concentrations of $\mathrm{Fe}(\mathrm{II}) \mathrm{FZ}_{3}$ were measured using Visible Spectroscopy. ${ }^{5}$ For measurement, 3 $\mathrm{mL}$ of the sample was continuously circulated through a $1 \mathrm{~m}$ path length type II liquid waveguide capillary cell (World Precision Instruments). The absorbance of the solution was measured at $562 \mathrm{~nm}$ using an Ocean Optics fiber optic spectrophotometry system with correction for baseline drift applied by subtracting the absorbance at $690 \mathrm{~nm}$. Calibration was performed immediately before experiments by standard addition of $\mathrm{Fe}(\mathrm{II})$ to the buffer solution containing $1.0 \mathrm{mM} \mathrm{FZ}$ and $10.0 \mathrm{mg} . \mathrm{L}^{-1} \mathrm{SRFA}$.

\section{S1.4 Hydrogen Peroxide Measurement}

For measurement of $\mathrm{H}_{2} \mathrm{O}_{2}$ production in irradiated SRFA solutions, $3 \mathrm{~mL}$ of SRFA solution was irradiated in a $1 \mathrm{~cm}$ quartz cuvette for $1,2,5$, and $10 \mathrm{~min}$. Following irradiation, $60 \mu \mathrm{L}$ of 100.0 $\mu \mathrm{M}$ AR and 50.0 kU.L-1 HRP mixture was added and fluorescence was measured using 
a Cary Eclipse spectrophotometer. Prior to experiments, calibration was performed by standard addition of $\mathrm{H}_{2} \mathrm{O}_{2}$ to $3 \mathrm{~mL}$ of $10.0 \mathrm{mg} . \mathrm{L}^{-1}$ SRFA solution.

\section{S1.5 Production and Measurement of Superoxide Stock Solution}

To generate $\mathrm{O}_{2}^{\bullet-}$ stock solution used for calibration of superoxide, $3 \mathrm{~mL}$ of solution containing $4 \% \mathrm{v} / \mathrm{v}$ ethanol and $0.4 \% \mathrm{v} / \mathrm{v}$ acetone in $\mathrm{pH} 11.5$ borate buffer was irradiated using a low pressure mercury vapour pen lamp (Pen-Ray) attached to a $1 \mathrm{~cm}$ quartz cuvette. To prevent the catalysed dismutation of $\mathrm{O}_{2}^{--}$by trace metals such as copper, $1.5 \mu \mathrm{M}$ of diethylenetriaminepentaacetic acid (DTPA) was added to the acetone/ethanol solution. The generation of $\mathrm{O}_{2}^{\bullet-}$ was monitored by UV absorption measurements at $240 \mathrm{~nm}$ using a USB4000 spectrometer (Ocean Optics) coupled to a deuterium and halogen DH2000 UV-VIS-NIR light source (Micropack). The measured absorbance was background corrected to account for any vertical drift by subtracting the absorbance measured at $320 \mathrm{~nm}$. OOIBase 32 spectroscopy software (OceanOptics) was employed for recording the absorbance measurements. A molar absorptivity of $2345 \mathrm{M}^{-1} . \mathrm{cm}^{-1}$ at $240 \mathrm{~nm}$, as reported earlier, ${ }^{6}$ was used for calculation of the stock concentration.

\section{S1.6 Superoxide Measurement}

Superoxide was measured using the chemiluminescence (CL) method employing MCLA as the reagent. ${ }^{3}$ The reaction of MCLA yielded $\mathrm{O}_{2}^{--}$specific CL that was detected by the FeLume (Waterville Analytical) system's photomultiplier tube. Note that singlet oxygen that may also be generated on irradiation of SRFA ${ }^{7}$ and is known to react with MCLA ${ }^{8}$ does not interfere in $\mathrm{O}_{2}^{\cdot-}$ measurement due to its short-lifetime (few $\mu \mathrm{s}$ ). ${ }^{9}$ Prior to measurement of $\mathrm{O}_{2}^{\cdot-}$ concentration generated on irradiation of SRFA, calibration was performed by addition of a known volume of $\mathrm{O}_{2}^{\circ-}$ stock solution to $\mathrm{pH} 8.3$ solution containing $10.0 \mathrm{mg} . \mathrm{L}^{-1}$ SRFA and 10.0 
$\mathrm{mM} \mathrm{NaCl}$. Since the sample takes $\sim 30 \mathrm{~s}$ to reach $\mathrm{CL}$ cell, a large proportion of the $\mathrm{O}_{2}^{\bullet-}$ decays even before the first sample point is measured. Since, the added $\mathrm{O}_{2}^{--}$undergoes rapid decay mostly via SRFA-catalysed disproportionation (note that uncatalysed disproportionation of $\mathrm{O}_{2}^{--}$is much slower than the SRFA catalysed $\mathrm{O}_{2}^{--}$decay ${ }^{10}$ ), the $\mathrm{O}_{2}^{\cdot-}$ concentration overtime is given by the expression:

$\left[\mathrm{O}_{2}^{\cdot-}\right]=\left[\mathrm{O}_{2}^{\bullet-}\right]_{0} e^{-k_{\mathrm{d}} t}$

where $k_{\mathrm{d}}$ represents the pseudo-first order rate constant for SRFA catalyzed $\mathrm{O}_{2}^{\bullet-}$ dismutation.

Assuming that the FeLume response ( $\mathrm{S}$, in intensity counts) is a linear function of $\left[\mathrm{O}_{2}^{--}\right]$such that $\mathrm{S}=\mathrm{C}\left[\mathrm{O}_{2}^{--}\right]$where $\mathrm{C}$ (counts.nM-1 ${ }^{-1}$ ) is a calibration coefficient, then $\mathrm{C}=\mathrm{S}_{0} /\left[\mathrm{O}_{2}^{--}\right]_{0}$ where $\mathrm{S}_{0}$ is the FeLume signal at time zero. The FeLume signal as a function of time is therefore:

$\mathrm{S}=\mathrm{S}_{0} e^{-k_{\mathrm{d}} t}$

Equation S2 was fitted to the FeLume data by non-linear regression of $S$ against $t$ using GraphPad Prism with $\mathrm{S}_{0}$ and $k_{\mathrm{d}}$ as fitting parameters. The assumption of linear calibration was valid over the concentration range employed in this study since the regression of $\left[\mathrm{O}_{2}^{--}\right]_{0}$ against values of $\mathrm{S}_{0}$ obtained were linear with an $R^{2} \geq 0.9$ for all the concentrations of $\mathrm{O}_{2}^{--}$employed.

The CL signal corresponding to $\mathrm{O}_{2}^{\circ-}$ concentration generated following irradiation of SRFA for $0.5,1,2,5$ and 10 min was measured immediately after extinguishing the lamp. However, as mentioned earlier a large proportion of the $\mathrm{O}_{2}^{--}$decays even before the first sample point is measured. Hence, the actual CL signal corresponding to $\mathrm{O}_{2}^{--}$concentration generated was calculated by log-linear extrapolation of the measured CL signal overtime. The extrapolated 
signal was then normalized with respect to calibration coefficient $(\mathrm{C})$ determined earlier to calculate the concentration of $\mathrm{O}_{2}^{\cdot-}$ generated on irradiation of SRFA i.e.:

$$
\left[\mathrm{O}_{2}^{\bullet-}\right]=\mathrm{S} / \mathrm{C}
$$

where $\mathrm{S}$ represents the extrapolated CL signal corresponding to $\mathrm{O}_{2}^{--}$concentration formed following irradiation of SRFA.

\subsection{Calculation of Fe(III) Speciation for varying Fe(III) and SRFA Concentration}

We calculated the concentration of $\mathrm{Fe}(\mathrm{III})$ present as $\mathrm{Fe}(\mathrm{III}) \mathrm{L}$ and AFO-L when varying concentration of $\mathrm{Fe}$ (III) was added to $10.0 \mathrm{mg} \cdot \mathrm{L}^{-1}$ SRFA solution using the reported SRFA binding capacity, $\mathrm{Fe}(\mathrm{III}) \mathrm{L}$ complexation and dissociation rate constant, $\mathrm{Fe}(\mathrm{III})$ precipitation rate constant at $\mathrm{pH} 8$ in the earlier studies. ${ }^{11,12}$ The reactions and rate constants for speciation calculation are shown in Table S1. Since analytical solution for these reactions is complex, we used the modelling software Kintek ${ }^{13}$ to numerically find the equilibrium concentration of AFO and $\mathrm{Fe}(\mathrm{III}) \mathrm{L}$.

Table S1 Reactions and rate constants used for Fe(III) speciation calculation

\begin{tabular}{|c|c|c|c|}
\hline No & Reaction & Rate constant $\left(\mathrm{M}^{-1} \mathrm{~s}^{-1}\right)$ & Reference \\
\hline 1 & 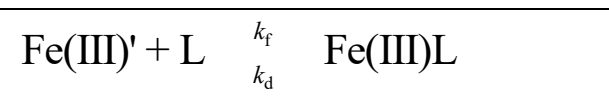 & $k_{\mathrm{f}}=6 \times 10^{6 \mathrm{a} ;} k_{\mathrm{d}}=6 \times 10^{-5} \mathrm{~s}^{-1}$ & 11 \\
\hline 2 & $\mathrm{Fe}(\mathrm{III})^{\prime}+\mathrm{Fe}(\mathrm{III})^{\prime} \longrightarrow \mathrm{AFO}+\mathrm{AFO}$ & $1.1 \times 10^{7}$ & 12 \\
\hline 3 & $\mathrm{Fe}(\mathrm{III})^{\prime}+\mathrm{AFO} \longrightarrow \mathrm{AFO}+\mathrm{AFO}$ & $4 \times 10^{6}$ & 12 \\
\hline
\end{tabular}

\subsection{Measurement of Fe Speciation using Filtration and Acidification Method}

We also measured the concentration of Fe(III) present as Fe(III)L and AFO-L using the filtration and acidification method described in our earlier work. ${ }^{14}$ Briefly, we measured the 
fraction of total Fe present in $0.025 \mu \mathrm{m}$ filtrate (namely the dissolved $\mathrm{Fe}$ ) which usually include organically-complexed $\mathrm{Fe}$ and/or inorganic $\mathrm{Fe}^{15}$ but may also include small AFO particles stabilized by the presence of organics. Furthermore, we also measured the acid-labile fraction of $\mathrm{Fe}>0.025 \mu \mathrm{m}$ during short-acidification step ( $1 \mathrm{~min}$ ) which principally results from the dissociation of organically complexed Fe(III). The concentration of total Fe was measured using the method described in our earlier work. ${ }^{14}$ Briefly, $1.0 \mathrm{mM} \mathrm{FZ}$ and $1.0 \mathrm{mM}$ hydroxylamine hydrochloride were added to the samples to reduce all $\mathrm{Fe}(\mathrm{III})$ to $\mathrm{Fe}(\mathrm{II})$ and trap $\mathrm{Fe}(\mathrm{II})$ formed as $\mathrm{Fe}(\mathrm{II}) \mathrm{FZ}_{3}$. After waiting for $24-48 \mathrm{~h}$ to ensure complete $\mathrm{Fe}(\mathrm{III})$ reduction had occurred, an appropriate volume of 5.0 $\mathrm{M}$ ammonium acetate was added to adjust the $\mathrm{pH}$ to 4.0 and the concentration of $\mathrm{Fe}(\mathrm{II}) \mathrm{FZ}_{3}$ was measured using the Ocean Optics spectrophotometry system described earlier. 


\section{S2 Additional Experimental Results}

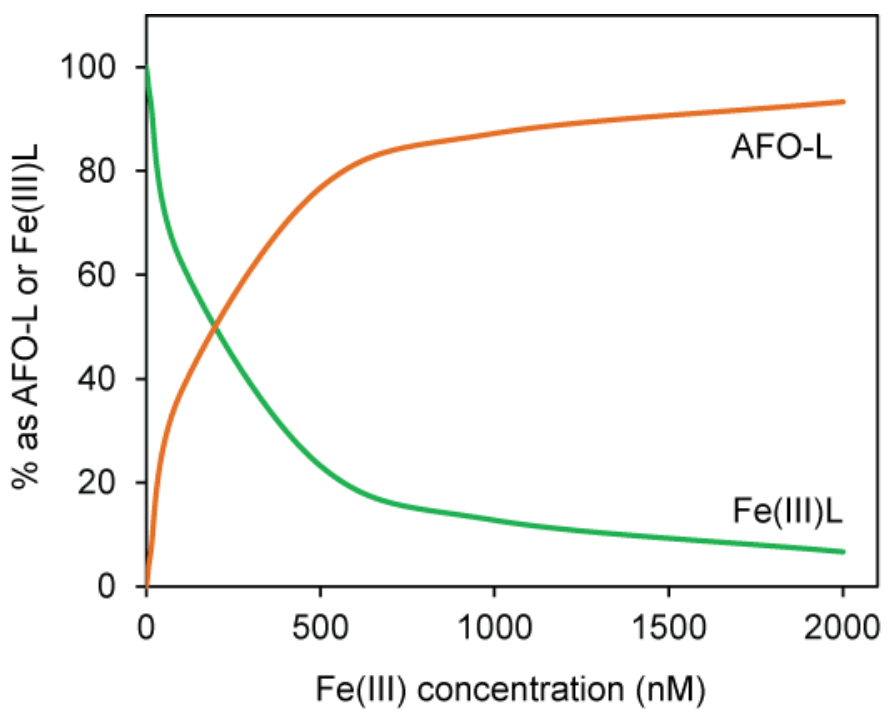

Figure S2: Calculated concentration of AFO-L and Fe(III)L formed in $\mathrm{pH} 8.3$ solution containing 10.0 mg. $\mathrm{L}^{-1}$ SRFA solution using the reactions shown in Table S1 for varying $\mathrm{Fe}(\mathrm{III})$ concentration in the presence of $10.0 \mathrm{mg} . \mathrm{L}^{-1}$ SRFA solution.
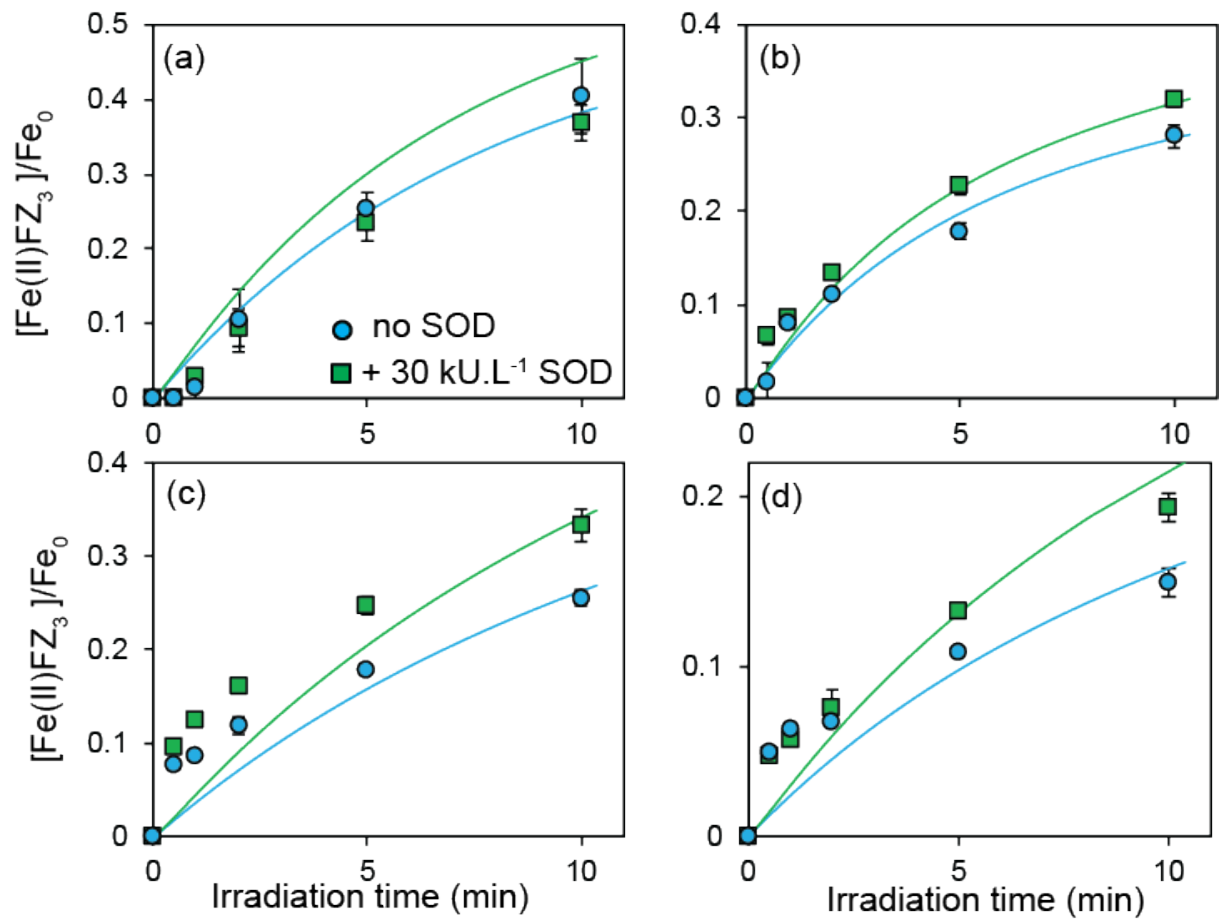

Figure S3: Generation of $\mathrm{Fe}(\mathrm{II}) \mathrm{FZ}_{3}$ in the absence (squares) and presence (circles) of $30 \mathrm{kU} . \mathrm{L}^{-}$

${ }^{1} \mathrm{SOD}$ on photochemical reduction of (a) $0.1 \mu \mathrm{M}$, (b) $0.5 \mu \mathrm{M}$, (c) $1.0 \mu \mathrm{M}$ and (d) $2.0 \mu \mathrm{M}$ Fe(III) 
when added to $10.0 \mathrm{mg} . \mathrm{L}^{-1}$ SRFA solution and incubated for $2 \mathrm{~h}$ prior to irradiation. Symbols represent the average of triplicate measurements; lines represent model results.

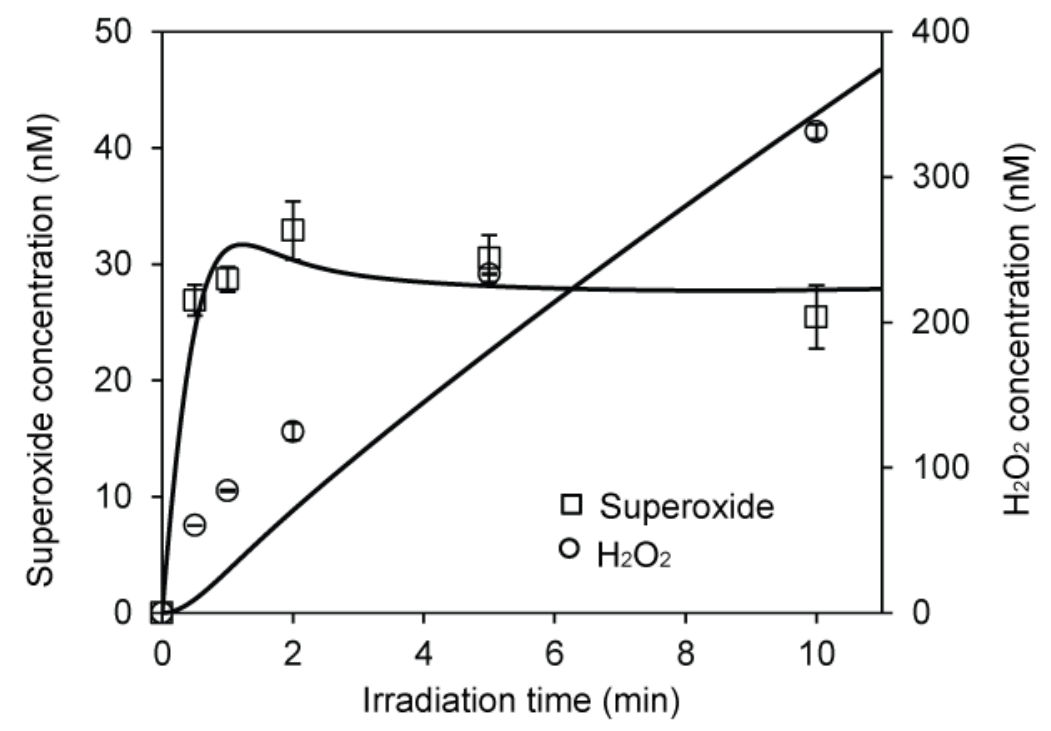

Figure S4: Measured concentration of $\mathrm{O}_{2}^{--}$and $\mathrm{H}_{2} \mathrm{O}_{2}$ formed on irradiation of $10.0 \mathrm{mg} . \mathrm{L}^{-1}$ SRFA. Symbols represent experimental data and lines represent model results.
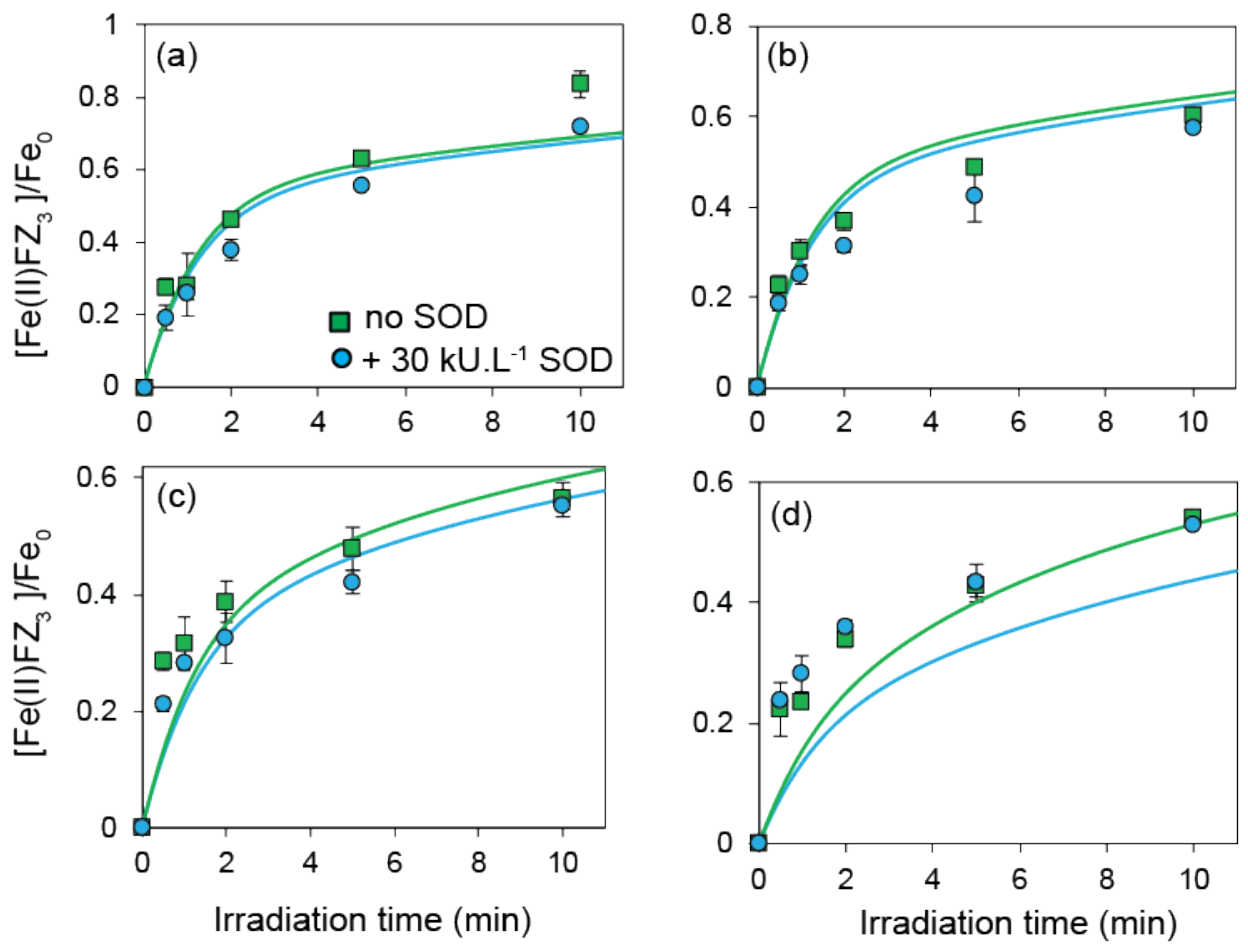
Figure S5: Generation of $\mathrm{Fe}(\mathrm{II}) \mathrm{FZ}_{3}$ on reduction of (a) $0.1 \mu \mathrm{M}$, (b) $0.5 \mu \mathrm{M}$, (c) $1.0 \mu \mathrm{M}$ and (d)

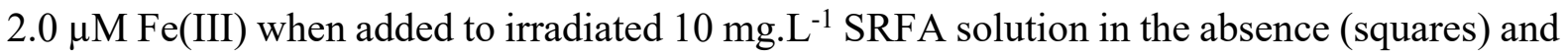
presence (circles) of $30 \mathrm{kU} . \mathrm{L}^{-1} \mathrm{SOD}$ at $\mathrm{pH}$ 6.8. Symbols represent the average of triplicate measurements.

Table S2: Contribution of SMIR to AFO reduction at $\mathrm{pH} 8.3$ under varying age and concentration of AFO

\begin{tabular}{|c|c|c|}
\hline AFO & Age of & $\%$ AFO reduction \\
\hline concentration & $\mathrm{AFO}$ & occurring via \\
\hline$(\mu \mathrm{M})$ & $(\min )$ & SMIR $^{\mathrm{a}}$ \\
\hline \multirow[t]{5}{*}{0.5} & 0.5 & 78.8 \\
\hline & 10 & 71.8 \\
\hline & 20 & 65.0 \\
\hline & 30 & 64.1 \\
\hline & 60 & 51.4 \\
\hline \multirow[t]{4}{*}{2.0} & 0.5 & 36.6 \\
\hline & 5 & 20.3 \\
\hline & 10 & 13.9 \\
\hline & 60 & ND \\
\hline
\end{tabular}

${ }^{a}$ calculated using the difference between the measured $\mathrm{Fe}(\mathrm{II}) \mathrm{FZ}_{3}$ concentration in the absence and presence of SOD after 10 min of irradiation. 
Table S3: Measured iron speciation in the presence of $10.0 \mathrm{mg} . \mathrm{L}^{-1} \mathrm{SRFA}$ at $\mathrm{pH} 8.3$

\begin{tabular}{|c|c|c|c|}
\hline \multirow{3}{*}{$\begin{array}{c}\text { Total Fe(III) } \\
(\mathrm{nM})\end{array}$} & \multicolumn{3}{|c|}{ Size fractionated Fe (nM) } \\
\hline & \multirow{2}{*}{$\begin{array}{l}\text { Dissolved Fe(III) } \\
\quad(<0.025 \mu \mathrm{m})\end{array}$} & \multicolumn{2}{|c|}{ Colloidal Fe(III) } \\
\hline & & Colloidal Fe(III)L & Colloidal AFO \\
\hline 100 & $65.2 \pm 3.2$ & ND & $40.9 \pm 4.5$ \\
\hline 500 & $288.4 \pm 8.1$ & $39.5 \pm 9.8$ & $172.2 \pm 12.7$ \\
\hline 1000 & $546.4 \pm 3.1$ & $115.5 \pm 3.8$ & $338.1 \pm 4.9$ \\
\hline 2000 & $1093.3 \pm 15.2$ & $265.3 \pm 30.8$ & $641.5 \pm 34.2$ \\
\hline
\end{tabular}

\section{S3: Description of the Kinetic Model to Explain Photochemical Fe(III) reduction at pH 8.3}

As shown in figures 1 and 2 in the main manuscript, the kinetic model shown in Table 1 provides an excellent description of the experimental results under various conditions. The reactions for the photo-generation and decay of ROS $\left(\mathrm{O}_{2}^{--}\right.$and $\left.\mathrm{H}_{2} \mathrm{O}_{2}\right)$, semiquinone-radical generation (Reactions 1-11, Table 1) are same as that reported in our earlier work. ${ }^{2}$ Reactions 12-13 represents formation and transformation of $\mathrm{Fe}(\mathrm{III}) \mathrm{L}$ to less reactive form (Fe(III) $\left.\mathrm{L}^{\prime}\right)$ respectively and are same as reported in our earlier work. ${ }^{2}$ Reactions $14-17$ represents the thermal reduction of $\mathrm{Fe}(\mathrm{III}) \mathrm{L}$ by hydroquinone and semiquinone-like entities as reported in our earlier work. ${ }^{2}$ Please refer to our earlier work for detailed description of these reactions. ${ }^{2} \mathrm{~A}$ brief description of the key reactions accounting for AFO formation and dissolution and photochemical Fe(III) (including Fe(III)L and AFO) reduction via SMIR and LMCT pathway as well as the justification of the rate constants used is provided below. Note that the thermal reduction of AFO by hydroquinone and semiquinone-like entities is not included here since no $\mathrm{Fe}(\mathrm{II})$ formation on AFO reduction was observed in non-irradiated SRFA solution. 


\section{S3.1 Formation, Dissolution and Aging of AFO}

Reactions 18-19 represent the formation of AFO via reaction mechanism reported in earlier work. ${ }^{12}$ The rate constant used here are same as that reported earlier. ${ }^{12,16}$ Reaction 20 represents the dissolution of AFO, the rate constant of which changes with the aging of AFO ${ }^{17}$ Reaction 21 represents the transformation of AFO to less reactive/inert form. The rate constant for the aging of AFO was determined based on best-fit to our experimental results and is dependent on the solution conditions with the rate constant increasing with increase in AFO concentration.

\section{S3.1 Fe(III) Reduction via LMCT}

Reactions 22 and 23 (Table 1) represent Fe(III)L and Fe(III)L' reduction by LMCT with the rate constant for these reactions same as that reported in our earlier work. ${ }^{2}$ The reduction rate constant of $\mathrm{Fe}(\mathrm{III}) \mathrm{L}^{\prime}$ is lower than that determined for Fe(III)L most likely as a result of its more stable conformation which impedes the electron-transfer process. Reactions 24 and 25 represents LMCT-mediated reduction of AFO and $\mathrm{Fe}(\mathrm{III})^{\prime}$ (formed on dissolution of AFO). The rate constant for reaction 24 was determined based on best-fit to our experimental results while the rate constant for reaction 25 was used as reported earlier. ${ }^{18}$ We would like to highlight that reaction 25 is not important in the experimental system investigated here since the reduction of $\mathrm{Fe}(\mathrm{III})$ by $\mathrm{O}_{2}^{--}$occurs at a much faster rate.

\section{$\mathrm{S3.8}$ Fe(III) Reduction by $\mathrm{O}_{2}^{\bullet-}$}

Reactions 26-28 (Table 1) represent the reduction of inorganic Fe(III) (i.e. Fe(III)') and SRFAcomplexed $\mathrm{Fe}(\mathrm{III})$ (i.e. $\mathrm{Fe}(\mathrm{III}) \mathrm{L}$ and $\mathrm{Fe}(\mathrm{III}) \mathrm{L}^{\prime}$ ) by $\mathrm{O}_{2}^{\bullet-}$. The rate constant for $\mathrm{Fe}(\mathrm{III})^{\prime}$ by $\mathrm{O}_{2}^{\bullet-}$

is same as that reported earlier. ${ }^{19}$ The rate constant for $\mathrm{Fe}(\mathrm{III}) \mathrm{L}$ reduction by $\mathrm{O}_{2}^{\bullet-}$ was determined based on best-fit to our experimental results and is consistent with the value 
reported earlier for the $\mathrm{O}_{2}^{\bullet-}$-mediated reduction of $\mathrm{Fe}(\mathrm{III})$ complexed by various organic moieties. ${ }^{20}$ The rate constant for $\mathrm{Fe}(\mathrm{III}) \mathrm{L}^{\prime}$ reduction by $\mathrm{O}_{2}^{\cdot-}$ is not well constrained by our experimental results; however is expected to be much lower than the rate constant determined for $\mathrm{Fe}(\mathrm{III}) \mathrm{L}$ and $\mathrm{O}_{2}^{\cdot-}$ interaction.

\section{S4: Extrapolation of the Kinetic Model to Predict SMIR Contribution to Fe(III) reduction}

For prediction of SMIR contribution at $\mathrm{pH} 6.8$, the rate constant for reactions 1-17 are same as that reported in our earlier work for $\mathrm{pH} 6.8 .^{2}$ The rate constant for reaction 18 was same as that reported earlier for $\mathrm{pH} 6.5$ while the rate constant for reactions 19-21 and reactions 24-28 were determined based on best-fit to our experimental results at $\mathrm{pH} 6.8$ (Figure S5) and are similar to the values determined at $\mathrm{pH} 8.3$.

For prediction of SMIR contribution in the presence of Elliot Soil humic acid, the rate constant for $\mathrm{O}_{2}^{--}$generation and decay were varied such that the steady-state $\mathrm{O}_{2}^{--}$concentration is three times higher than that measured in the presence of SRFA as was reported to be the case in an earlier study. ${ }^{21}$ We also varied the rate constant for reaction 12 (i.e. binding of Fe(III) by Elliott Soil humic acid) using the reported rate constant and binding capacity for Elliott Soil humic acid in an earlier study by Fujii and co-workers. ${ }^{11}$ 


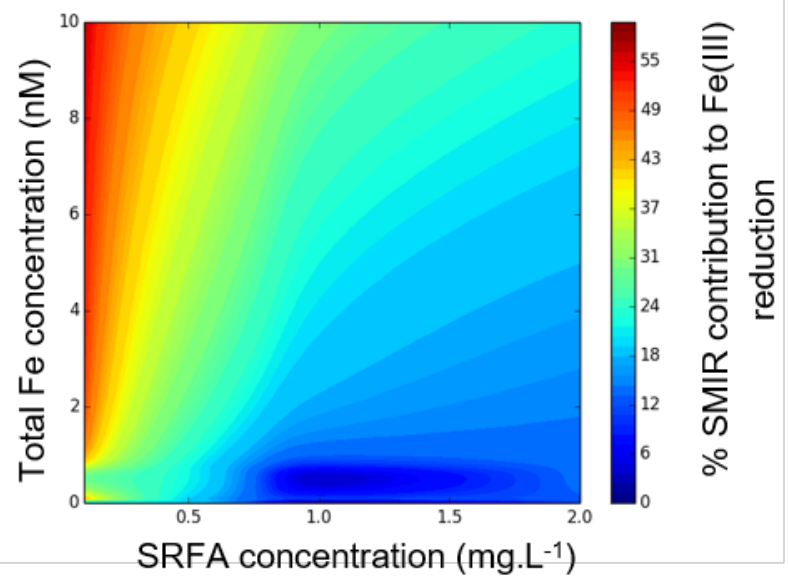

Figure S6: Model predicted contribution of SMIR to photochemical Fe(III) reduction in the presence of varying SRFA and total Fe(III) concentration at $\mathrm{pH}$ 8.3.
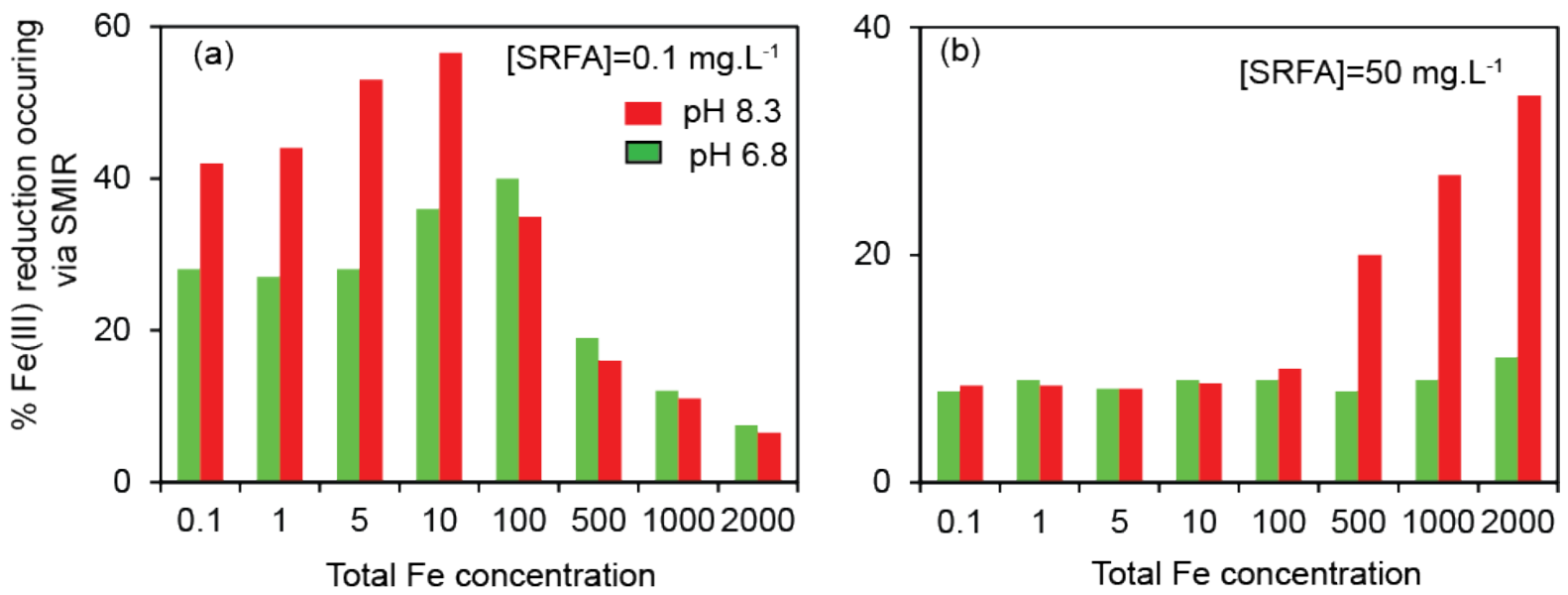

Figure S7: Model predicted contribution of SMIR to Fe(III) reduction in the presence of (a) $0.1 \mathrm{mg} . \mathrm{L}^{-1}$ and (b) $50 \mathrm{mg} . \mathrm{L}^{-1} \mathrm{SRFA}$ at $\mathrm{pH} 8.3$ (red bars) and 6.8 (green bars). 


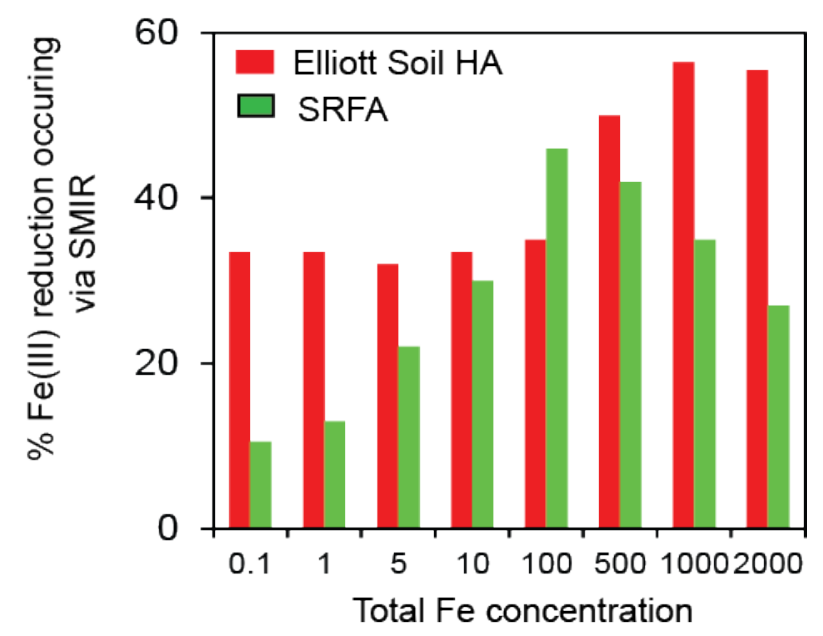

Figure S8: Model predicted contribution of SMIR to Fe(III) reduction in the presence of 1.0 mg.L $\mathrm{L}^{-1}$ Elliott Soil HA (red bars) and SRFA (green bars) at $\mathrm{pH}$ 8.3.

\section{References}

1. Garg, S.; Ito, H.; Rose, A. L.; Waite, T. D., Mechanism and Kinetics of Dark Iron Redox Transformations in Acidic Previously Photolyzed Acidic Natural Organic Matter Solutions Environ. Sci. Technol 2013, 47, 1861-1867.

2. Garg, S.; Jiang, C.; Waite, T. D., Impact of $\mathrm{pH}$ on Iron Redox Transformations in Simulated Freshwaters Containing Natural Organic Matter. Environ. Sci. Technol 2018, 52, 13184-13194.

3. Boland, N. E. Quantification of Nanomolar Superoxide in Aqueous Solution: Flow Injection Analysis Using the Chemiluminescent Reagent MCLA. Honours thesis, Colby College, Waterville, Maine, 2001.

4. Zhou, M.; Diwu, Z.; Panchuk-Voloshina, N.; Haugland, R. P., A stable nonfluorescent derivative of resorufin for the fluorometric determination of trace hydrogen peroxide: Applications in detecting the activity of phagocyte NADPH oxidase and other oxidases. Analytical Biochemistry 1997, 253, 162-168.

5. Stookey, L. L., Ferrozine: a new spectrophotometric reagent for iron. Analytical Chemistry 1970, 42, 779-781.

6. Bielski, B. H. J., Reevaluation of the spectral and kinetic properties of $\mathrm{HO}_{2}$ and $\mathrm{O}_{2}{ }^{-}$free radicals. Photochemistry and Photobiology 1978, 28, (4-5), 645-649.

7. Garg, S.; Rose, A. L.; Waite, T. D., Photochemical Production of Superoxide and Hydrogen Peroxide from Natural Organic Matter Geochimica et Cosmochimica Acta 2011, 74, 4310-4320.

8. Fujimori, K.; Komiyama, T.; Tabata, H.; Nojima, T.; Ishiguro, K.; Sa-waki, Y.; Tatsuzawa, H.; Nakano, M., Chemiluminescence of Cypridina Luciferin Analogs. Part 3. MCLA Chemiluminescence with Singlet Oxygen Generated by the Retro - Diels - Alder Reaction of a Naphthalene Endoperoxide. Photochemistry and Photobiology 1998, 68, 143149.

9. Dalrymple, R. M., Correlations between Dissolved Organic Matter Optical Properties and Quantum Yields of Singlet Oxygen and Hydrogen Peroxide. Environmental Science \& Technology 2010, 44, 5824-5829. 
10. Goldstone, J. V.; Voelker, B. M., Chemistry of superoxide radical in seawater: CDOM associated sink of superoxide in coastal waters. Environmental Science and Technology 2000, 34, 1043-1048.

11. Fujii, M.; Imaoka, A.; Yoshimura, C.; Waite, T. D., Effects of Molecular Composition of Natural Organic Matter on Ferric Iron Complexation at Circumneutral pH. Environ. Sci. Technol 2014, 48, 4414-4424.

12. Pham, A. N.; Rose, A. L.; Feitz, A. J.; Waite, T. D., Kinetics of Fe(III) precipitation in aqueous solutions at $\mathrm{pH}$ 6.0-9.5 and $25^{\circ} \mathrm{C}$. Geochimica et Cosmochimica Acta 2006, 70, (3), 640-650.

13. Johnson, K. A.; Simpson, Z. B.; Blom, T., Global Kinetic Explorer: A new computer program for dynamic simulation and fitting of kinetic data. . Analytical Biochemistry 2009, 387, 20-29.

14. Wang, K.; Garg, S.; Waite, T. D., Redox Transformations of Iron in the Presence of Exudate from the Cyanobacterium Microcystis aeruginosa under Conditions Typical of Natural Waters. Environ. Sci. Technol 2017, 51, 3287-3297.

15. Fujii, M.; Ito, H.; Rose, A. L.; Waite, T. D.; Omura, T., Transformation dynamics and reactivity of dissolved and colloidal iron in coastal waters. Mar Chem 2008, 110, 165-175.

16. Bligh, M. W.; Waite, T. D., Formation, aggregation and reactivity of amorphous ferric oxyhydroxides on dissociation of Fe(III)-organic complexes in dilute aqueous suspensions. Geochimica et Cosmochimica Acta 2010, 74, 5746-5762.

17. Fujii, M.; Rose, A. L.; Waite, T. D.; Omura, T., Superoxide-Mediated Dissolution of Amorphous Ferric Oxyhydroxide in Seawater Environmental Science and Technology 2006, 40, 880-887.

18. Borer, P.; Sulzberger, B.; Hug, S. J.; Kraemer, S. M.; Kretzschmar, R., Photoreductive Dissolution of Iron(III) (Hydr)oxides in the Absence and Presence of Organic Ligands: Experimental Studies and Kinetic Modeling. Environmental Science \& Technology 2009, 43, (6), 1864-1870.

19. Rush, J. D.; Bielski, B. H. J., Pulse radiolytic studies of the reactions of $\mathrm{HO}_{2} / \mathrm{O}_{2}^{-}$with $\mathrm{Fe}(\mathrm{II}) / \mathrm{Fe}(\mathrm{III})$ ions. The reactivity of $\mathrm{HO}_{2} / \mathrm{O}_{2}{ }^{-}$with ferric ions and its implication on the occurrence of the Haber-Weiss reaction. Journal of Physical Chemistry 1985, 89, 5062-5066.

20. Fujii, M.; Rose, A. L.; Waite, T. D.; Omura, T., Oxygen and superoxide-mediated redox kinetics of iron complexed by humic substances in coastal seawater. . Environ. Sci. Technol 2010, 44, 9337-9342.

21. Fujii, M.; Otani, E., Photochemical generation and decay kinetics of superoxide and hydrogen peroxide in the presence of standard humic and fulvic acids. Water Research 2017, 123, 642-654. 